\title{
Programa de intermediación laboral para personas con discapacidad: "Listos para el trabajo" Andrea Zondek
}

\section{Resumen}

Este artículo presenta los lineamientos centrales que guían la acción del Fondo Nacional de la Discapacidad (FONADIS) en materias de equiparación de oportunidades e inserción laboral de personas con discapacidad. En este documento da cuenta de los principales avances, resultados y aprendizajes obtenidos durante la primera etapa del proceso de implementación, sistematización y evaluación del Programa de Intermediación Laboral para personas con discapacidad de FONADIS.

Se abordan los tres ejes fundamentales del modelo de intervención del programa: la persona con discapacidad como trabajador, el mercado laboral formal, y la labor de intermediación de un equipo especializado. Finalmente, en este artículo se revisan los aspectos más relevantes y las proyecciones futuras de este innovador programa, que en su primer año de ejecución ha puesto en marcha tres Oficinas de Intermediación Laboral para personas con discapacidad (OIL) en diferentes regiones del país.

\section{Abstract}

This article presents the central features that guide the action of the National Fund of the Disability (FONADIS) in matters of equalizing of opportunities and labor insertion of persons with disability.

In this document gives account of the main advances, results and learning's obtained during the first phase of the process of implementation, systematization and evaluation of the Intermediation Labor Program for persons with disability of FONADIS. This work undertakes the three fundamental axes of intervention model of the program: the person with disability as worker, the formal labor market, and the work of intermediation of an equipment specialized. Finally, in this article the most prominent aspects are revised and the future projections of this innovator programs that in its first year of execution there is position in motion of three Offices of Intermediation Labor for persons with disability (OIL) in different regions of the country. 